\title{
Association between Maternal Omega-3-Fatty Acid and Hypothyroidism: Unhealthy Baby and Brain Disorders
}

\author{
Ahmed R.G* \\ Division of Anatomy and Embryology, Zoology Department, Faculty of Science, Beni-Suef University, Beni- \\ Suef, Egypt
}

*Corresponding Author: Ahmed R.G, Division of Anatomy and Embryology, Zoology Department, Faculty of Science, Beni-Suef University, Beni-Suef, Egypt, Email: ahmedragab08@gmail.com

\section{COMMENTARY}

Maternal diet and programs of gestational nutrition, in particular, omega-3 fatty acid may be crucial for a successful pregnancy, delivery, fetal, neonatal and child health outcomes (Greenberg et al., 2008; Sinha et al., 2009; Osendarp, 2011; Klemens et al., 2012; Swanson et al., 2012; Akerele and Cheema, 2016; Nordgren et al., 2017). Also, the normal levels of omega-3 fatty acid can regulate and protect the developing central nervous system (CNS) (Farquharson et al., 1995; Su et al., 1999; Bowen and Clandinin, 2005; DeMar et al., 2005; McNamara and Carlson, 2006). Accordingly, timely maternal thyroid hormones (THs; 3,5,3'-triiodothyronine (T3) and thyroxine (T4)) signaling is critical for the CNS development during the prenatal and postnatal periods (Ahmed, 2011, 2012a,b, 2013, 2014, 2015a-c, 2016a-d, 2017a-v, 2018a-w; Ahmed and Ahmed, 2012; Ahmed et al., 2013a,b, 2014, 2015a,b, 2018a,b; Van Herck et al., 2013; Ahmed and El-Gareib, 2014; Incerpi et al., 2014; Candelotti et al., 2015; De Vito et al., 2015; El-Ghareeb et al., 2016; Ahmed and ElGareib, 2017).

On the other hand, there are associations between the amount and quality of gestational dietary fats and health consequences of both dams and their offspring (Makrides et al., 2011; Emmett et al., 2015). Omega-3 fatty acid supplementations have vital roles during pregnancy and can decrease the maternal brain disorders and the maternofetal and neonatal complications, and enhance the neonatal neurocognitive consequences (Olsen et al., 2007; Emmett et al., 2015; Miyata and Arita, 2015; Lauritzen et al., 2016), and visual insight (Uauy et al., 2003; Makrides et al., 2011; Campoy et al., 2012). Alternatively, my group reported that gestational hypothyroidism in rat caused several permanent disorders in the developing CNS including neuronal necrosis and apoptosis in different brain regions (Ahmed et al., 2008; 2010; 2012; El-bakry et al., 2010; Ahmed and Incerpi, 2013). These disorders are categorized by increased mitochondrial disorders including induced expression of proapoptotic protein $\mathrm{Bax}$ and diminish in antiapoptotic Bcl-2 and $\mathrm{Bcl}-\mathrm{x}_{\mathrm{L}}$ proteins (Singh et al., 2003; Sadamatsu et al., 2006; de Escobar et al., 2007; Opazo et al., 2008). These disruptions can increase the risk of numerous neurodevelopmental diseases. Thus, dietary Omega-3 fatty acid intake during the gestation can prevent apoptosis decreasing the proapoptotic protein Bax and increasing antiapoptotic Bcl-2 and Bcl- $\mathrm{x}_{\mathrm{L}}$ proteins (Lonergan et al., 2002; Akbar et al., 2005; Rao et al., 2007; Mukherjee et al., 2007).

In conclusion, the current overview supposed that the normal balance in the levels of dietary omega-3-fatty acids (anti-inflammatory actions) and maternal THs may be necessary for the normal brain development during the prenatal and postnatal periods. In addition, the deficiency in their levels during the gestation may increase the risk of teratogenic consequences and brain disorders (depression, psychotic symptoms, mental retardation, schizophrenia, Alzheimer, cognitive dysfunction, and mood disability) in fetuses, neonates, and childhood. These disturbances may increase the susceptibility of the CNS to the inflammatory-immune diseases, may decrease the neurite growth, and may inhibit the development generally. However, their developmental, molecular and biochemical mechanisms are unclear until now. The disruptions in the fetal and neonatal development may be depending on the time and 
severity of these deficiencies. Thus, this report can be recommended the following: (1) avoid the deficiency in levels of dietary omega-3-fatty acids and maternal THs; (2) Pregnant can keep the normal levels of dietary omega-3-fatty acids by eating the fatty fish such as salmon, tuna, and trout; (3) overconsumption of fishes should be avoided for the mercury toxicity; and (4) following the levels of maternal THs before or during pregnancy to decrease or avoid the previous disorders. Additional experiments are important to study the influence of the deficiency in levels of dietary omega-3-fatty acids and maternal THs at different stages of pregnancy (following pregnancy duration and birth dimensions) on the developing neuroendocrine system of both fetuses and neonates. The developmental, molecular, biochemical and immunological mechanisms should be examined. This could support development novel therapeutic approaches and enhance maternal and infant health consequences.

\section{REFERENCES}

[1] Ahmed, O.M., Abd El-Tawab, S.M., Ahmed, R.G., 2010. Effects of experimentally induced maternal hypothyroidism and hyperthyroidism on the development of rat offspring: I- The development of the thyroid hormonesneurotransmitters and adenosinergic system interactions. Int. J. Dev. Neurosci. 28, 437-454.

[2] Ahmed, O.M., Ahmed, R.G., 2012. Hypothyroidism. In A New Look at Hypothyroidism. Dr. D. Springer (Ed.), ISBN: 978-953-51-0020-1), In Tech Open Access Publisher, Chapter 1, pp. 1-20.

[3] Ahmed, O.M., Ahmed, R.G., El-Gareib, A.W., El-Bakry, A.M., Abd El-Tawab, S.M., 2012. Effects of experimentally induced maternal hypothyroidism and hyperthyroidism on the development of rat offspring: II-The developmental pattern of neurons in relation to oxidative stress and antioxidant defense system. Int. J. Dev. Neurosci. 30, 517-537.

[4] Ahmed, O.M., El-Gareib, A.W., El-bakry, A.M., Abd El-Tawab, S.M., Ahmed, R.G., 2008. Thyroid hormones states and brain development interactions. Int. J. Dev. Neurosci. 26(2), 147-209. Review.

[5] Ahmed, R.G., 2011. Perinatal 2, 3, 7, 8tetrachlorodibenzo-p-dioxin exposure alters developmental neuroendocrine system. Food Chem. Toxicology, 49, 1276-1284.

[6] Ahmed, R.G., 2012a. Maternal-newborn thyroid dysfunction. In the Developmental Neuroendocrinology, pp. 1-369. Ed R.G.
Ahmed. Germany: LAP LAMBERT Academic Publishing GmbH \& Co KG.

[7] Ahmed, R.G., 2012b. Maternal-fetal thyroid interactions, Thyroid Hormone, Dr. N.K. Agrawal (Ed.), ISBN: 978-953-51-0678-4, In Tech Open Access Publisher, Chapter 5, pp. 125-156.

[8] Ahmed, R.G., 2013. Early weaning PCB 95 exposure alters the neonatal endocrine system: thyroid adipokine dysfunction. J. Endocrinol. 219 (3), 205-215.

[9] Ahmed, R.G., 2014. Editorial: Do PCBs modify the thyroid-adipokine axis during development? Annals Thyroid Res. 1(1), 11-12.

[10] Ahmed, R.G., 2015a. Chapter 1: Hypothyroidism and brain development. In advances in hypothyroidism treatment. Avid Science Borsigstr. 9, 10115 Berlin, Berlin, Germany. Avid Science Publications level 6, Melange Towers, Wing a, Hitec City, Hyderabad, Telangana, India. pp. 1-40.

[11] Ahmed, R.G., 2015b. Hypothyroidism and brain developmental players. Thyroid Research J. 8(2), 1-12.

[12] Ahmed, R.G., 2015c. Editorials and Commentary: Maternofetal thyroid action and brain development. J. of Advances in Biology; 7(1), 1207-1213.

[13] Ahmed, R.G., 2016a. Gestational dexamethasone alters fetal neuroendocrine axis. Toxicology Letters, 258, 46-54.

[14] Ahmed, R.G., 2016b. Neonatal polychlorinated biphenyls-induced endocrine dysfunction. Ann. Thyroid. Res. 2 (1), 34-35.

[15] Ahmed, R.G., 2016c. Maternal iodine deficiency and brain disorders. Endocrinol. Metab. Syndr. 5, 223. http://dx.doi.org/10.4172/2161-1017.1000223.

[16] Ahmed, R.G., 2016d. Maternal bisphenol A alters fetal endocrine system: Thyroid adipokine dysfunction. Food Chem. Toxicology, 95, 168-174.

[17] Ahmed, R.G., 2017a. Developmental thyroid diseases and GABAergic dysfunction. EC Neurology 8.1, 02-04.

[18] Ahmed, R.G., 2017b. Hyperthyroidism and developmental dysfunction. Arch Med. 9, 4.

[19] Ahmed, R.G., 2017c. Anti-thyroid drugs may be at higher risk for perinatal thyroid disease. EC Pharmacology and Toxicology 4.4, 140142.

[20] Ahmed, R.G., 2017d. Perinatal hypothyroidism and cytoskeleton dysfunction. Endocrinol Metab Syndr 6, 271. doi:10.4172/2161-1017. 1000271

[21] Ahmed, R.G., 2017e. Developmental thyroid diseases and monoaminergic dysfunction. 
Advances in Applied Science Research 8(3), 01-10.

[22] Ahmed, R.G., 2017f. Hypothyroidism and brain development. J. Anim Res Nutr. 2(2), 13.

[23] Ahmed, R.G., 2017g. Antiepileptic drugs and developmental neuroendocrine dysfunction: Every why has A Wherefore. Arch Med 9(6), 2.

[24] Ahmed, R.G., 2017h. Gestational prooxidantantioxidant imbalance may be at higher risk for postpartum thyroid disease. Endocrinol Metab Syndr 6, 279. doi:10.4172/2161-1017.1000279.

[25] Ahmed, R.G., 2017i. Synergistic actions of thyroid-adipokines axis during development. Endocrinol Metab Syndr 6, 280. doi:10.4172/2161-1017.1000280.

[26] Ahmed, R.G., 2017j. Thyroid-insulin dysfunction during development. International Journal of Research Studies in Zoology 3(4), 73-75. DOI: http://dx.doi.org/10.20431/2454941X.0304010.

[27] Ahmed, R.G., 2017k. Developmental thyroid diseases and cholinergic imbalance. International Journal of Research Studies in Zoology 3(4), 70-72. DOI: http://dx.doi.org/ 10.20431/2454-941X.0304009.

[28] Ahmed, R.G., 20171. Thyroid diseases and developmental adenosinergic imbalance. Int $\mathbf{J}$ Clin Endocrinol 1(2), 053-055.

[29] Ahmed, R.G., 2017m. Maternal anticancer drugs and fetal neuroendocrine dysfunction in experimental animals. Endocrinol Metab Syndr 6, 281. doi:10.4172/2161-1017.1000281.

[30] Ahmed, R.G., 2017n. Letter: Gestational dexamethasone may be at higher risk for thyroid disease developing peripartum. Open Journal of Biomedical \& Life Sciences (Ojbili) 3(2), 01-06.

[31] Ahmed, R.G., 2017o. Deiodinases and developmental hypothyroidism. EC Nutrition 11.5, 183-185.

[32] Ahmed, R.G., 2017p. Maternofetal thyroid hormones and risk of diabetes. Int. J. of Res. Studies in Medical and Health Sciences 2(10), 18-21.

[33] Ahmed, R.G., 2017r. Association between hypothyroidism and renal dysfunctions. International Journal of Research Studies in Medical and Health Sciences 2(11), 1-4.

[34] Ahmed, R.G., 2017s. Maternal hypothyroidism and lung dysfunction. International Journal of Research Studies in Medical and Health Sciences 2(11), 8-11.

[35] Ahmed, R.G., 2017t. Endocrine disruptors; possible mechanisms for inducing developmental disorders. International journal of basic science in medicine (IJBSM) 2(4), $157-160$.
[36] Ahmed, R.G., 2017u. Maternal thyroid hormones trajectories and neonatal behavioral disorders. ARC Journal of Diabetes and Endocrinology 3(2), 18-21.

[37] Ahmed, R.G., 2017v. Maternal thyroid dysfunction and neonatal cardiac disorders. Insights Biol Med. 1, 092-096.

[38] Ahmed, R.G., 2018a. Maternal hypothyroidism and neonatal testicular dysfunction. International Journal of Research Studies in Medical and Health Sciences 3(1), 8-12.

[39] Ahmed, R.G., 2018b. Maternal hypothyroidism and neonatal depression: Current perspective. International Journal of Research Studies in Zoology 4(1), 6-10. DOI: http://dx.doi.org/10.20431/2454941X.0401002.

[40] Ahmed, R.G., 2018c. Non-genomic actions of thyroid hormones during development. App Clin Pharmacol Toxicol: ACPT-108. DOI: 10.29011/ACPT-109. 100008.

[41] Ahmed, R.G., 2018d. Maternal thyroid function and placental hemodynamics. ARC Journal of Animal and Veterinary Sciences 4(1), 9-13. DOI: $\quad$ http://dx.doi.org/10.20431/24552518.0401002 .

[42] Ahmed, R.G., 2018e. Interactions between thyroid and growth factors during development. ARC Journal of Diabetes and Endocrinology 4(1), 1-4. DOI: http://dx.doi.org/10.20431/2455-5983.0401001.

[43] Ahmed, R.G., 2018f. Maternal thyroid hormones and neonatal appetite. ARC Journal of Nutrition and Growth 4(1), 18-22. DOI: http://dx.doi.org/10.20431/2455-2550.0401005.

[44] Ahmed, R.G., 2018g. Genomic actions of thyroid hormones during development. ARC Journal of Diabetes and Endocrinology 4(1), 58. DOI: http://dx.doi.org/10.20431/2455-598 3.0401002.

[45] Ahmed, R.G., 2018h. Dysfunction of maternal thyroid hormones and psychiatric symptoms. American Research Journal of Endocrinology. 2(1), 1-6.

[46] Ahmed, R.G., 2018i. Is there a connection between maternal hypothyroidism and developing autism spectrum disorders? ARC Journal of Neuroscience 3(1), 5-8. DOI: http:// dx.doi.org/10.20431/2456-057X.0301002002.

[47] Ahmed, R.G., 2018j. Maternal thyroid dysfunctions and neonatal bone maldevelopment. American Research Journal of Endocrinology (in press) xx-xxx.

[48] Ahmed, R.G., 2018k. Maternal thyroid disorders and risk of neonatal seizure: Current perspective. ARC Journal of Neuroscience 3(1), 21-25. DOI: http://dx.doi.org/10.20431 /2456 -057X.0301004 
[49] Ahmed, R.G., 20181. Gestational dioxin acts as developing neuroendocrine-disruptor. EC Pharmacology and Toxicology 6.3, 96-100.

[50] Ahmed, R.G., 2018m. Maternal thyroid dysfunction and risk of neonatal stroke. ARC Journal of Animal and Veterinary Sciences 4(1),22-26. DOI:http://dx.doi.org/10.20431/ 2455-2518.0401004

[51] Ahmed, R.G., 2018n. Maternal thyroid disorders and developing skin dysfunctions. ARC Journal of Dermatology 3(1), 13-17. DOI: http://dx.doi.org/10.20431/2456-0022.0301005

[52] Ahmed, R.G., 2018o. Maternal hypothyroidism-milk ejections: What is the link? ARC Journal of Nutrition and Growth 4(1), 29-33. DOI: http://dx.doi.org/10.20431 /2455-2550.0401007

[53] Ahmed, R.G., 2018p. Does maternal antepartum hypothyroidism cause fetal and neonatal hyponatremia? ARC Journal of Diabetes and Endocrinology 4(1), xx-xxx. DOI: http://dx.doi.org/10.20431/2455-5983. 0401004

[54] Ahmed, R.G., 2018q. Maternal hypothyroidism and rheumatoid arthritis. International Journal of Research Studies in Medical and Health Sciences Volume 3(2), 1-5.

[55] Ahmed, R.G., 2018r. Developmental thyroid and skeletal muscle dysfunction. ARC Journal of Diabetes and Endocrinology 4(1), xx-xxx. DOI: http://dx.doi.org/10.20431/2455-5983. 0401003 .

[56] Ahmed, R.G., 2018s. Hyperthyroidism and renal disorders. ARC Journal of Animal and Veterinary Sciences 4(2), XX-XX. DOI: http://dx.doi.org/10.20431/2455-2518.0402001

[57] Ahmed, R.G., 2018t. Maternal hypothyroidism and developing hyperhomocysteinemia. ARC Journal of Nutrition and Growth 4(2), xx-xxx. DOI: $\quad$ http://dx.doi.org/10.20431/24552550.0402002

[58] Ahmed, R.G., 2018u. Maternal hyperthyroidism and neonatal testicular dysfunction. ARC Journal of Urology 3(1), xxxxx. DOI: http://dx.doi.org/10.20431/2456060X.0301002

[59] Ahmed, R.G., 2018v. Maternal hypothyroidism-developing dyslipidemia: What is the connection? ARC Journal of Pharmaceutical Sciences (AJPS) 4(1), 1-6. DOI: $\quad$ http://dx.doi.org/10.20431/24551538.0401001

[60] Ahmed, R.G., 2018w. Maternal iodine deficiency and pregnancy complications: Still a health issue for the pregnant and fetuses. ARC Journal of Pharmaceutical Sciences (AJPS) 4(1), 7-11. DOI: http://dx.doi.org/10.20431 /2455-1538.0401002
[61] Ahmed, R.G., Abdel-Latif, M., Ahmed F., 2015a. Protective effects of GM-CSF in experimental neonatal hypothyroidism. International Immunopharmacology 29, 538543.

[62] Ahmed, R.G., Abdel-Latif, M., Mahdi, E., ElNesr, K., 2015b. Immune stimulation improves endocrine and neural fetal outcomes in a model of maternofetal thyrotoxicosis. Int. Immunopharmacol. 29, 714-721.

[63] Ahmed, R.G., Davis, P.J., Davis, F.B., De Vito, P., Farias, R.N., Luly, P., Pedersen, J.Z., Incerpi, S., 2013a. Nongenomic actions of thyroid hormones: from basic research to clinical applications. An update. Immunology, Endocrine \& Metabolic Agents in Medicinal Chemistry, 13(1), 46-59.

[64] Ahmed, R.G., El-Gareib, A.W. 2014. Lactating PTU exposure: I- Alters thyroid-neural axis in neonatal cerebellum. Eur. J. of Biol. and Medical Sci. Res. 2(1), 1-16.

[65] Ahmed, R.G., El-Gareib, A.W., 2017. Maternal carbamazepine alters fetal neuroendocrinecytokines axis. Toxicology 382, 59-66.

[66] Ahmed, R.G., El-Gareib, A.W., Incerpi, S., 2014. Lactating PTU exposure: II- Alters thyroid-axis and prooxidant-antioxidant balance in neonatal cerebellum. Int. Res. J. of Natural Sciences 2(1), 1-20.

[67] Ahmed, R.G., El-Gareib, A.W., Shaker, H.M., 2018a. Gestational 3,3',4,4',5pentachlorobiphenyl (PCB 126) exposure disrupts fetoplacental unit: Fetal thyroidcytokines dysfunction. Life Sciences 192, 213220.

[68] Ahmed, R.G., Incerpi, S., 2013. Gestational doxorubicin alters fetal thyroid-brain axis. Int. J. Devl. Neuroscience 31, 96-104.

[69] Ahmed, R.G., Incerpi, S., Ahmed, F., Gaber, A., 2013b. The developmental and physiological interactions between free radicals and antioxidant: Effect of environmental pollutants. J. of Natural Sci. Res. 3(13), 74110.

[70] Ahmed, R.G., Walaa G.H., Asmaa F.S., 2018 b. Suppressive effects of neonatal bisphenol A on the neuroendocrine system. Toxicology and Industrial Health Journal (in press).

[71] Akbar, M., Calderon, F., Wen, Z., Kim, H.Y., 2005. Docosahexaenoic acid: a positive modulator of Akt signaling in neuronal survival. Proc. Natl. Acad. Sci. U.S.A. 102, 10858-10863.

[72] Akerele, O.A., Cheema, S.K., 2016. A balance of omega-3 and omega- 6 polyunsaturated fatty acids is important in pregnancy. Journal of Nutrition \& Intermediary Metabolism 5, 23-33. 
[73] Bowen, R.A., Clandinin, M.T., 2005. Maternal dietary $22: 6 n-3$ is more effective than $18: 3 n-3$ in increasing the 22:6n-3 content in phospholipids of glial cells from neonatal rat brain, Br. J. Nutr. 93, 601-611.

[74] Campoy, C., Escolano-Margarit, M.V., Anjos, T., Szajewska, H., Uauy, R., 2012. Omega 3 fatty acids on child growth, visual acuity and neurodevelopment. Br. J. Nutr. 107, 85-106.

[75] Candelotti, E., De Vito, P., Ahmed, R.G., Luly, P., Davis, P.J., Pedersen, J.Z., Lin, H-Y., Incerpi, I., 2015. Thyroid hormones crosstalk with growth factors: Old facts and new hypotheses. Immun., Endoc. \& Metab. Agents in Med. Chem., 15, 71-85.

[76] de Escobar, G.M., Obregon, M.J., del Rey, F.E., 2007. Iodine deficiency and brain development in the first half of pregnancy. Public Health Nutr. 10, 1554-1570.

[77] De Vito, P., Candelotti, E., Ahmed, R.G., Luly, P., Davis, P.J., Incerpi, S., Pedersen, J.Z., 2015. Role of thyroid hormones in insulin resistance and diabetes. Immun., Endoc. \& Metab. Agents in Med. Chem., 15, 86-93.

[78] DeMar, J.C. Ma, K. Chang, L., Bell, J.M., Rapoport, S.I., 2005. Alpha-Linolenic acid does not contribute appreciably to docosahexaenoic acid within brain phospholipids of adult rats fed a diet enriched in docosahexaenoic acid, J. Neurochem. 94, 1063-1076.

[79] El-bakry, A.M., El-Ghareeb, A.W., Ahmed, R.G., 2010. Comparative study of the effects of experimentally-induced hypothyroidism and hyperthyroidism in some brain regions in albino rats. Int. J. Dev. Neurosci. 28, 371-389.

[80] El-Ghareeb, A.A., El-Bakry, A.M., Ahmed, R.G., Gaber, A., 2016. Effects of zinc supplementation in neonatal hypothyroidism and cerebellar distortion induced by maternal carbimazole. Asian Journal of Applied Sciences 4(04), 1030-1040.

[81] Emmett, P.M., Jones, L.R., Golding, J., 2015. Pregnancy diet and associated outcomes in the avon longitudinal study of parents and children. Nutr. Rev. 73, 154-174.

[82] Farquharson, J., Jamieson, E.C., Abbasi, K.A., Patrick, W.J., Logan, R.W., Cockburn, F., 1995. Effect of diet on the fatty acid composition of the major phospholipids of infant cerebral cortex, Arch. Dis. Child 72, 198-203.

[83] Greenberg, J.A., Bell, S.J., Ausdal, W.V., 2008. Omega-3 fatty acid supplementation during pregnancy. Rev Obstet Gynecol. 1(4), 162-169.

[84] Incerpi, S., Hsieh, M-T., Lin, H-Y., Cheng, GY., De Vito, P., Fiore, A.M., Ahmed, R.G., Salvia, R., Candelotti, E., Leone, S., Luly, P.,
Pedersen, J.Z., Davis, F.B., Davis, P.J., 2014. Thyroid hormone inhibition in L6 myoblasts of IGF-I-mediated glucose uptake and proliferation: new roles for integrin $\alpha v \beta 3$. Am. J. Physiol. Cell Physiol. 307, C150-C161.

[85] Klemens, C.M., Salari, K., Mozurkewich, E.L., 2012. Assessing omega-3 fatty acid supplementation during pregnancy and lactation to optimize maternal mental health and childhood cognitive development, Clinical Lipidology, 7(1), 93-109.

[86] Lauritzen, L., Brambilla, P., Mazzocchi, A., Harslof, L.B., Ciappolino, V., 2016. Agostoni, C. DHA Effects in Brain Development and Function. Nutrients 8, 6 .

[87] Lonergan, P.E., Martin, D.S., Horrobin, D.F., Lynch, M.A., 2002. Neuroprotective effect of eicosapentaenoic acid in hippocampus of rats exposed to gamma-irradiation. J. Biol. Chem. 277, 20804-20811.

[88] Makrides, M., Collins, C.T., Gibson, R.A., 2011. Impact of fatty acid status on growth and neurobehavioural development in humans. Matern. Child Nutr. 7, 80-88.

[89] McNamara, R.K., Carlson, S.E., 2006. Role of omega-3 fatty acids in brain development and function: Potential implications for the pathogenesis and prevention of Psychopathology. Prostaglandins, Leukotrienes and Essential Fatty Acids doi: 10.1016/j.plefa.2006.07.010.

[90] Miyata, J., Arita, M., 2015. Role of omega-3 fatty acids and their metabolites in asthma and allergic diseases. Allergol. Int. 64, 27-34.

[91] Mukherjee, P.K., Marcheselli, V.L., Barreiro, S., Hu, J., Bok, D., Bazan, N.G., 2007. Neurotrophins enhance retinal pigment epithelial cell survival through neuroprotection D1 signaling. Proc. Natl. Acad. Sci. U.S.A. 104, 13152-13157.

[92] Nordgren, T.M., Lyden, E., Anderson-Berry, A., Hanson, C., 2017. Omega-3 fatty acid intake of pregnant women and women of childbearing age in the United States: Potential for deficiency? Nutrients 9(197), 1-12. doi:10.3390/nu9030197.

[93] Olsen, S.F., Osterdal, M.L., Salvig, J.D., Weber, T., Tabor, A., Secher, N.J., 2007. Duration of pregnancy in relation to fish oil supplementation and habitual fish intake: A randomised clinical trial with fish oil. Eur. J. Clin. Nutr. 61, 976-985.

[94] Opazo, M.C., Gianini, A., Pancetti, F., Azkcona, G., Alarcon, L., Lizana, R., Noches, V., Gonzalez, P.A., Porto, M.,Mora, S., Rosenthal, D., Eugenin, E., Naranjo, D., Bueno, S.M., Kalergis, A.M., Riedel, C.A., 2008. Maternal hypothyroxinemia impairs spatial learning and synaptic nature and 
function in the offspring. Endocrinology 149, 5097-5106.

[95] Osendarp, S.J.M., 2011. The role of omega-3 fatty acids in child development. OCL 18(6), 307-313. doi: 10.1684/ocl.2011.0417

[96] Rao, J.S., Ertley, R.N., Lee, H.J., DeMar Jr., J.C., Arnold, J.T., Rapoport, S.I., Bazinet, R.P., 2007. n-3 polyunsaturated fatty acid deprivation in rats decreases frontal cortex BDNF via a p38 MAPK-dependent mechanism. Mol. Psychiatry 12, 36-46.

[97] Sadamatsu, M., Kanai, H., Xu, X., Liu, Y., Kato, N., 2006. Review of animal models for autism: implication of thyroid hormone. Congenit. Anom. (Kyoto) 46, 1-9.

[98] Singh, R., Upadhyay, G., Kumar, S., Kapoor, A., Kumar, A., Tiwari, M., Godbole, M.M., 2003. Hypothyroidism alters the expression of Bcl-2 family genes to induce enhanced apoptosis in the developing cerebellum. J. Endocrinol. 176, 39-46.

[99] Sinha, R.A., Khare, P., Rai, A., Maurya, S.K., Pathak, A., Mohan, V., Nagar, G.K., 2009. Anti-apoptotic role of omega-3-fatty acids in developing brain: perinatal hypothyroid rat cerebellum as apoptotic model. Int. J. Devl Neuroscience 27, 377-383.

[100] Su, H.M., Bernardo, L. Mirmiran, M., Ma, X.H., Corso, T.N., Nathanielsz, P.W., Brenna, J.T., 1999. Bioequivalence of dietary alphalinolenic and docosahexaenoic acids as sources of docosahexaenoate accretion in brain and associated organs of neonatal baboons, Pediatr. Res. 45, 87-93.

[101] Swanson, D., Block, R., Mousa, S.A., 2012. Omega-3 fatty acids EPA and DHA: Health benefits throughout life. Adv. Nutr. 3, 1-7.

[102] Uauy, R., Hoffman, D.R., Mena, P., Llanos, A., Birch, E.E., 2003. Term infant studies of DHA and ARA supplementation on neurodevelopment: results of randomized controlled trials. J. Pediatr. 143, 17-25.

[103] Van Herck, S.L.J., Geysens, S., Bald, E., Chwatko, G., Delezie, E., Dianati, E., Ahmed, R.G., Darras, V.M., 2013. Maternal transfer of methimazole and effects on thyroid hormone availability in embryonic tissues. Endocrinol. $218,105-115$.

Citation: Ahmed R.G. Association between Maternal Omega-3-Fatty Acid and Hypothyroidism: Unhealthy Baby and Brain Disorders.ARC Journal of Nutrition and Growth.2018;4(2):15-20. DOI: dx.doi.org/ 10.20431/ 2455-2550.0402004.

Copyright: () 2018 Authors. This is an open-access article distributed under the terms of the Creative Commons Attribution License, which permits unrestricted use, distribution, and reproduction in any medium, provided the original author and source are credited. 